\title{
HYDROCHEMICAL PROPERTIES OF CAVE LAKE AND GROUND WATER FLOW IN THE CAVE OF SLATINSKI IZVOR IN THE DRY PERIOD OF THE YEAR
}

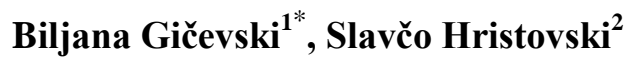 \\ ${ }^{1}$ Exploring Society "Ursus speleos", Skopje, Republic of Macedonia \\ ${ }^{2}$ Institute of Biology, Faculty of Natural Sciences and Mathematics, Ss. Cyril and Methodius University, \\ Skopje, Republic of Macedonia \\ *Corresponding author, e-mail: biljana_speleo@yahoo.com
}

The hydrochemical properties of the ground waters in the cave of Slatinski Izvor were analyzed monthly, from December 2011 to October 2013, in the dry period of the year (5 anions and 11 cations). Water was sampled at three points: the first one at $30 \mathrm{~m}$ from the cave's entrance, the second one at $800 \mathrm{~m}$ from the cave's entrance, and the third one in the cave lake at $1000 \mathrm{~m}$ distance from the cave's entrance. Four methods (Piper diagram, Stiff diagram, Chadha diagram, and D'Amore diagram) were applied in order to determine the hydrochemical properties of the water samples. The results showed that all water samples have the same origin, all water samples belong to $\mathrm{CaHCO}_{3}$ water type, water has temporary hardness, and the aquifer is composed of dolomite and limestone.

Key words: ground waters in cave of Slatinski Izvor; Piper diagram; Stiff diagram; Chadha diagram; D’Amore diagram

\section{INTRODUCTION}

Karst areas are found in about $15 \%$ of the Earth's surface [1], and karst aquifers hold significant amount of groundwater resources which is an important source of the drinking water. Because of the specific nature and unique hydrogeological characteristics, karst aquifers require specifically adapted hydrochemical methods because they are different from other hydrogeological environments. Usually, the karst springs are the main sampling points which provide information about the functioning of the karst system. But the interpretation of the data can be complicated by mixing of waters from different sub-catchments. Access points such as caves or man-made structures (borehole, artificial galleries) can help to avoid this difficulty of interpretation. Caves often provide access to water from the vadose zone (e.g. stalagmite drip water) and the saturated zone [2]. These access points provide information about the water quality and the hydrochemical composition of different compo- nents contributing to spring discharge. Hydrochemical analyses help to locate and quantify the mineralization of the water, provide information about the structure and dynamics of karst aquifer, and also help for understand the water-rock interactions. The physico-chemical characteristics of ground waters in karstic systems are determined by the lithology of the rocks which they cross, the physicchemical processes that predominate, the residence time of water and the various conditions and modes of circulation that coexist within them [3].

In the Poreche basin there are several karst springs (Pesna, Manastirec, Slatinski Izvor) which represent a significant potential for water supply. Until now, the water quality and hydrochemical characteristic of these springs as well as ground waters, have not been subject to analysis.

The main goal of the study was to determine the hydrochemical properties of the water samples from the cave of Slatinski Izvor (Poreče, Macedonia) and assess their possible origin. 


\section{SITE DESCRIPTION}

The Slatinski Izvor cave which is the object of interest in this paper is located in the Poreche basin, in the river valley of Slatinska Reka and it is a part of the protected area Monument of Nature Slatinski Izvor (Figure 1).

The cave is built in pre-Cambrian dolomite marbles which are tectonically crushed and well karstified. Its colour ranges from light grey to bright white, and it is composed of dolomite grains (0.1$0.4 \mathrm{~mm}$ in size), and also contains grains of calcite, quartz and muscovite [4]. The carbonate rocks are covered with Pliocene sediments (gravel, sends, and clay) which are well permeable with intergranular porosity. Quaternary sediments have alluvial origin and fill the river bed of the Slatinska Reka river, and they also have intergranular porosity (Figure 2).

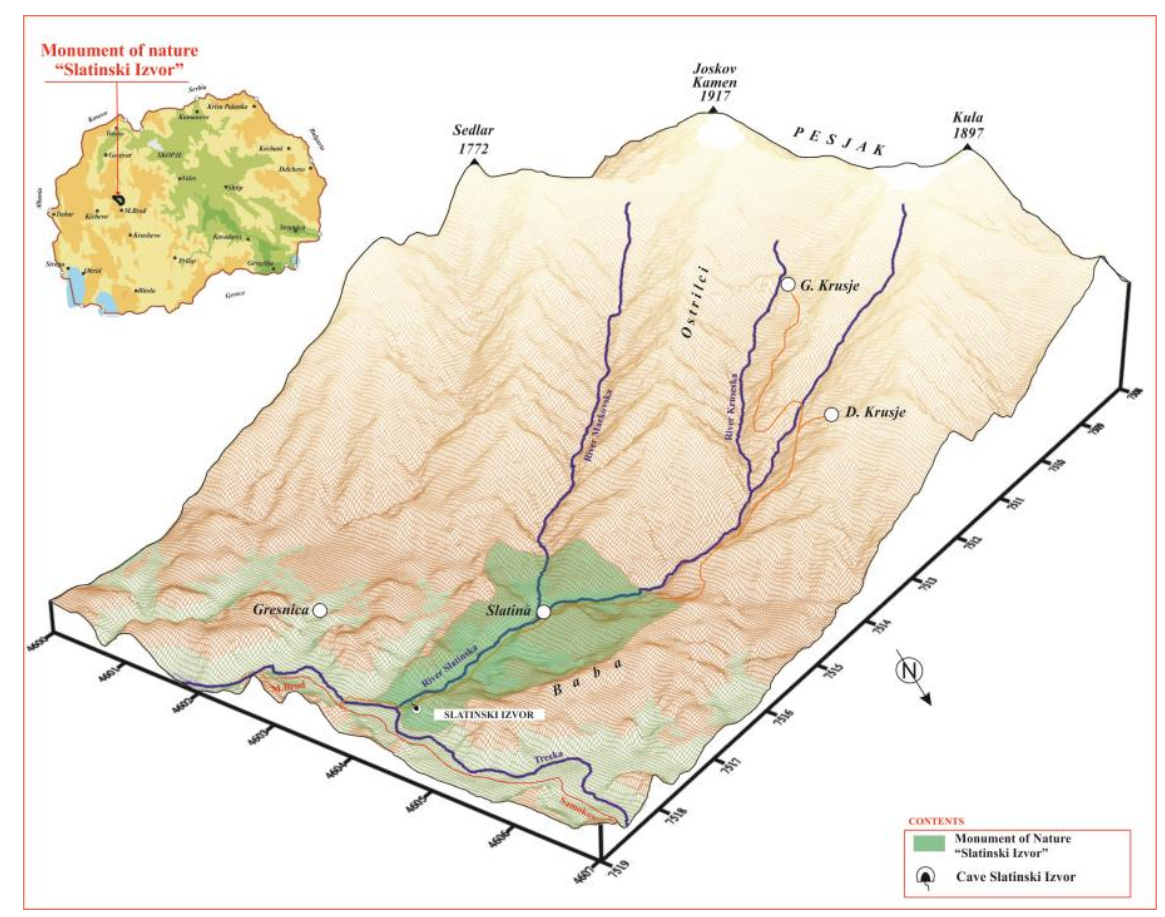

Figure 1. Geographical position of the Slatinski Izvor cave

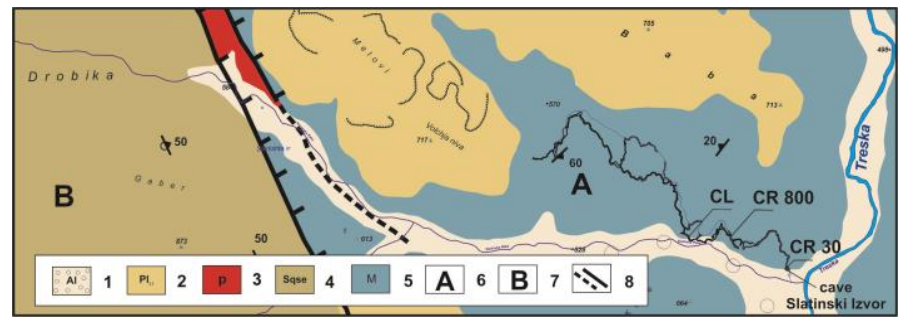

Figure 2. Simplified geological map

Legend: 1 - alluvial sediments, 2 - pliocene sediments, 3 - granite, 4 - noncarbonate rocks (schists), 5 - dolomite marbles, 6 - Pelagonian horst-anticlinorium tectonic unit, 7 - Western Macedonian tectonic unit, 8 - faults (according to Dumurđanov et al. [5])

The cave belongs to the Pelagonian horstanticlinorium tectonic unit which is separated from the Western Macedonian tectonic unit with a fault in NW-SE direction, traced for more than $50 \mathrm{~km} \mathrm{[6].}$ There is a reverse fault between the Slatina and Zrkle villages in NW-SE direction, and covered fault on the river bed of Kruševska Reka in NW-SE direction.
The cave of Slatinski Izvor is a spring cave and the karst spring of Slatinski Izvor serves as an entrance for one of the cave's entrances [7]. Cave river flows through most of the cave passages. According to the cave patterns [8] the cave is a branchwork cave with passages that join as tributaries. 


\section{EXPERIMENTAL SECTION}

In order to identify the chemical characteristics of the waters in the Slatinski Izvor cave, field measurements and laboratory analyses were carried out. These were the first continuous analyses of the Slatinski Izvor cave. The water samples were collected monthly, between December 2011 and November 2013, in the dry period of the year. A total of 25 water samples were collected, which were taken on three points: the first one at $30 \mathrm{~m}$ from the cave's entrance (CR30), the second one at $800 \mathrm{~m}$ from the cave's entrance (CR800), and the third one in the cave lake (CL) at $1000 \mathrm{~m}$ distance from the cave's entrance (Figure 2). There is no visual connection between CL and CR800. Water temperature, $\mathrm{pH}$ and specific conductivity were measured in-situ at the time of sample collection using fieldtype instruments, with a hand-held water quality meter. Samples were collected manually in polyethylene bottles. The hydrochemical properties were analyzed at the Institute of Biology, Faculty of Natural Sciences and Mathematics in Skopje. All water samples were filtered within 12 hours of collection and analyzed within 3-4 days. Sulphates were determined by photometric method of Dévai et al. [9] and chlorides by Mohr's method [10]. All of the cations were analyzed by wet digestion followed by atomic absorption spectrometry on Agilent $55 \mathrm{Z}$ and graphite furnace Agilent 240Z [11]. Total phosphorus was determined in the same digested material by the method of Fiske \& Subarow [12].

$\mathrm{The} \mathrm{Ca} / \mathrm{Mg}$ ratio was calculated as ratio between $\mathrm{Ca}$ and $\mathrm{Mg}$ expressed in meq $\cdot \mathrm{l}^{-1}$.

Piper diagram [13] was used for graphical presentation of the hydrochemical characteristics of the water samples. The major cations and anions are plotted in milligram per liter, in each triangle, then the plotting from triangular fields was extended further into the central diamond field. Piper diagram was used to make a conclusion on the origin of the waters and to study the similarities and differences in the composition of waters and to classify them into certain chemical types.

Stiff diagram [14] is a method in which an irregular polygon is constructed from four parallel horizontal axes extending on either side of a vertical zero axes. Cations are plotted on the left side of the zero axes, and anions are plotted on the right side, both in milliequivalents per liter $\left(\mathrm{meq} \cdot \mathrm{l}^{-1}\right.$ ). Each different pattern represents a different type of water. This diagram can be used if the flow path is known, to show how the ionic composition of water changes over space.

The hydrochemical evolution of water can be understood by plotting the major cations and anions in the Chadha diagram [15]. In this diagram the difference in milliequivalent percentage between alkaline earths (calcium plus magnesium) and alkali metals (sodium plus potassium), expressed as percentage reacting values, is plotted on the $X$ axis, and the difference in milliequivalent percentage between weak acidic anions (carbonate plus bicarbonate) and strong acidic anions (chloride plus sulphate) is plotted on the $Y$ axis. The milliequivalent percentage differences between alkaline earths and alkali metals, and between weak acidic anions and strong acidic anions, would plot in one of the four possible sub-fields of the proposed diagram. The square or rectangular field describes the overall character of the water. The diagram can be used to study various hydro chemical processes, such as base cation exchange, cement pollution, mixing of natural waters, sulphate reduction, saline water (end-product water), and other related hydrochemical problems.

Using basic cations and anions D'Amore et al. [16] determined six new parameters for distinguishing water groups based on the geological features of the main reservoir crossed by each water sample. Hydrochemical parameters are marked by letters from $\mathrm{A}$ to $\mathrm{F}$ :

$$
\begin{gathered}
\mathrm{A}: \frac{100}{\sum(-)}\left(\mathrm{HCO}_{3}^{-}-\mathrm{SO}_{4}^{2-}\right) \\
\mathrm{B}: 100\left(\frac{\mathrm{SO}_{4}^{2-}}{\sum(-)}-\frac{\mathrm{Na}^{+}}{\sum(+)}\right) \\
\mathrm{C}: 100\left(\frac{\mathrm{Na}^{+}}{\sum(+)}-\frac{\mathrm{Cl}^{-}}{\sum(-)}\right) \\
\mathrm{D}: 100\left(\frac{\mathrm{Na}^{+}-\mathrm{Mg}^{2+}}{\sum(+)}\right) \\
\text { E: } 100\left(\frac{\mathrm{Ca}^{2+}+\mathrm{Mg}^{2+}}{\sum(+)}-\frac{\mathrm{HCO}_{3}^{-}}{\sum(-)}\right) \\
\mathrm{F}: 100\left(\frac{\mathrm{Ca}^{2+}-\mathrm{Na}^{+}-\mathrm{K}^{+}}{\sum(+)}\right)
\end{gathered}
$$

Parameters define the ratio between dissolved species where square brackets represent concentrations in meq $\cdot 1^{-1}$, and range from +100 to $100 \mathrm{meql}^{-1}$. Sum $\Sigma$ represents the sum of cation $(+)$ and anion $(-)$ concentrations. Parameter A assists in distinguishing between water circulations through calcareous terrains and those occurring in evaporitic rocks. Parameter B discriminates between sulphate-enriched waters circulating in evaporitic terrains and sodium-enriched waters that encountered 
marly, clayey sedimentary terrains. Parameter C tends to distinguish between waters deriving from 'flysch' or 'volcanites' and those coming from carbonate-evaporitic series or from a regional quartizitic schistose basement. Parameter D individuates waters that have circulated in dolomitized limestone. Parameter E distinguishes between circulations in carbonate reservoirs and those in sulphate-bearing reservoirs. Parameter $\mathrm{F}$ reveals the increasing $\mathrm{K}^{+}$ concentration in the water samples.
The saturation indices describe quantitatively the deviation of water from equilibrium with respect to dissolved minerals. If the water is exactly saturated with the dissolving mineral, saturation index equals to zero. Positive values of saturation index indicate saturation/supersaturation, and negative ones indicate undersaturation. Saturation indices for anhydrite, aragonite, calcite, dolomite, gypsum and halite minerals were calculated using WATEQ4F computer program [17].

Table 1. Hydrochemical properties of the ground waters from the cave of Slatinski Izvor, for the period December 2011 - October 2013 (CV - coefficient of variation)

\begin{tabular}{|c|c|c|c|}
\hline & $\mathrm{CL}$ & CR800 & CR30 \\
\hline \multicolumn{4}{|l|}{$T /{ }^{\circ} \mathrm{C}$} \\
\hline Range & $11-12$ & $9.5-11$ & $9-11$ \\
\hline Mean & 11.64 & 10.3 & 10.3 \\
\hline $\mathrm{CV}$ & 0.03 & 0.05 & 0.06 \\
\hline \multicolumn{4}{|l|}{$p H$} \\
\hline Range & $7.0-8.2$ & $7.0-8.0$ & $7.0-8.2$ \\
\hline Mean & 7.68 & 7.74 & 7.81 \\
\hline $\mathrm{CV}$ & 0.05 & 0.05 & 0.05 \\
\hline \multicolumn{4}{|l|}{$E C\left(\mu S \cdot \mathrm{cm}^{-1}\right)$} \\
\hline Range & $200-300$ & $190-320$ & $190-340$ \\
\hline Mean & 271.42 & 256.66 & 281.11 \\
\hline $\mathrm{CV}$ & 0.16 & 0.18 & 0.22 \\
\hline \multicolumn{4}{|l|}{$T D S\left(m g \cdot l^{-1}\right)$} \\
\hline Range & $128-192$ & $121.6-204.8$ & $121.6-224$ \\
\hline Mean & 173.71 & 164.26 & 179.91 \\
\hline $\mathrm{CV}$ & 0.16 & 0.18 & 0.22 \\
\hline \multicolumn{4}{|l|}{$\mathrm{Ca}\left(\mathrm{mg} \cdot \mathrm{l}^{-1}\right)$} \\
\hline Range & $15.00-38.33$ & $9.59-32.65$ & $10.60-40.87$ \\
\hline Mean & 20.56 & 22.88 & 26.52 \\
\hline $\mathrm{CV}$ & 0.37 & 0.34 & 0.35 \\
\hline \multicolumn{4}{|l|}{$M g\left(m g \cdot l^{-1}\right)$} \\
\hline Range & $11.17-21.96$ & $8.07-20.18$ & $7.32-32.43$ \\
\hline Mean & 14.19 & 11.45 & 14.06 \\
\hline $\mathrm{CV}$ & 0.29 & 0.30 & 0.51 \\
\hline \multicolumn{4}{|l|}{$\mathrm{Cl}\left(m g \cdot l^{-1}\right)$} \\
\hline Range & $7.6-11.2$ & $9.4-20.8$ & $10.0-20.8$ \\
\hline Mean & 9.34 & 16.2 & 16.31 \\
\hline $\mathrm{CV}$ & 0.14 & 0.23 & 0.21 \\
\hline \multicolumn{4}{|l|}{$N a\left(m g \cdot l^{-1}\right)$} \\
\hline Range & $1.09-2.09$ & $1.16-6.42$ & $2.30-6.62$ \\
\hline Mean & 1.53 & 3.56 & 3.71 \\
\hline $\mathrm{CV}$ & 0.20 & 0.39 & 0.31 \\
\hline \multicolumn{4}{|l|}{$K\left(m g \cdot l^{-1}\right)$} \\
\hline Range & $0.18-0.62$ & $0.19-1.50$ & $0.62-1.55$ \\
\hline Mean & 0.38 & 0.78 & 0.87 \\
\hline $\mathrm{CV}$ & 0.35 & 0.43 & 0.31 \\
\hline \multicolumn{4}{|l|}{$\mathrm{SO}_{4}\left(m g \cdot l^{-1}\right)$} \\
\hline Range & $23.94-83.89$ & $12.28-37.25$ & $16.12-77.72$ \\
\hline Mean & 44.28 & 26.61 & 34.80 \\
\hline $\mathrm{CV}$ & 0.49 & 0.28 & 0.46 \\
\hline \multicolumn{4}{|l|}{$\mathrm{HCO}_{3}\left(m g \cdot l^{-1}\right)$} \\
\hline Range & $128.1-183.0$ & $183.0-225.7$ & $176.9-244.0$ \\
\hline Mean & 139.42 & 210.78 & 211.46 \\
\hline $\mathrm{CV}$ & 0.13 & 0.08 & 0.10 \\
\hline
\end{tabular}




\section{RESULTS AND DISCUSSION}

General hydrochemical properties of the ground waters from the cave of Slatinski Izvor

The hydrochemical properties of the ground waters are presented in Table 1. All water samples showed small temperature variations. The $\mathrm{pH}$ values showed that all water samples belong to the water group with alkaline reaction. All water samples contained more than $120 \mathrm{mg} \cdot \mathrm{l}^{-1}$ of dissolved solids, thus they had hard water [1].

The major ions in all water samples were dominantly $\mathrm{Ca}^{2+}>\mathrm{Mg}^{2+}>\mathrm{Na}^{+}$for the cations and $\mathrm{HCO}_{3}{ }^{-}>\mathrm{SO}_{4}{ }^{2-}>\mathrm{Cl}^{-}$for the anions. $\mathrm{HCO}_{3}{ }^{-}$and $\mathrm{SO}_{4}{ }^{2-}$ were dominant dissolved species in the water which indicate the predominant carbonate and quartz rocks in the aquifer.

According to Sawyer and McCarty's [18] classification all water samples were moderately hard $\left(75-150 \mathrm{mg} \cdot 1^{-1}\right)$.

The $\mathrm{Ca} / \mathrm{Mg}$ ratio provides information of the rock type through which the groundwater has passed. The values of $\mathrm{Ca} / \mathrm{Mg}$ ratio $\mathrm{CL}, \mathrm{CR} 800$ and CR30 were $0.87,1.24$ and 1.34 , respectively. The values show that the dolomite rocks have the dominant influence on $\mathrm{CL}$, whereas the limestone rocks have the dominant impact on CR800 and CR30.

\section{Grapho-analytical methods}

All water samples of the cave of Slatinski Izvor (CL, CR800 and CR30) showed similar characteristics. All of them are plotted near the left corner of the diamond on a Piper diagram (Figure 3) which showed that the water is reach in $\mathrm{Ca}^{2+}, \mathrm{Mg}^{2+}$ and $\mathrm{HCO}_{3}{ }^{-}$and is the region of water of temporary hardness. The aquifer is composed of dolomite. The chemical composition of the water is characterized by $\mathrm{Ca}-\mathrm{HCO}_{3}$ type which is typical of shallow and fresh waters.

Ionic composition of the cave waters is changed over space. Thus, Stiff diagram (Figure 4) shows that dolomite had an influence on cave lake water, whereas limestone had a dominant influence on the rest points of the cave river. Also, the content of calcium and bicarbonate concentration increased from CL to CR30.

All water samples of the cave river and cave lake are plotted on Chadha diagram (Figure 5), and they fall in the 5th sub-field. This indicates that alkaline earths $\left(\mathrm{Ca}^{2+}+\mathrm{Mg}^{2+}\right)$ and weak acidic anions $\left(\mathrm{CO}_{3}{ }^{2+}+\mathrm{HCO}_{3}{ }^{-}\right)$exceed both alkali metals $\left(\mathrm{Na}^{+}+\mathrm{K}^{+}\right)$and strong acidic anions $\left(\mathrm{Cl}^{-}+\mathrm{SO}_{4}{ }^{2-}\right)$, respectively. Such waters have temporary hardness.

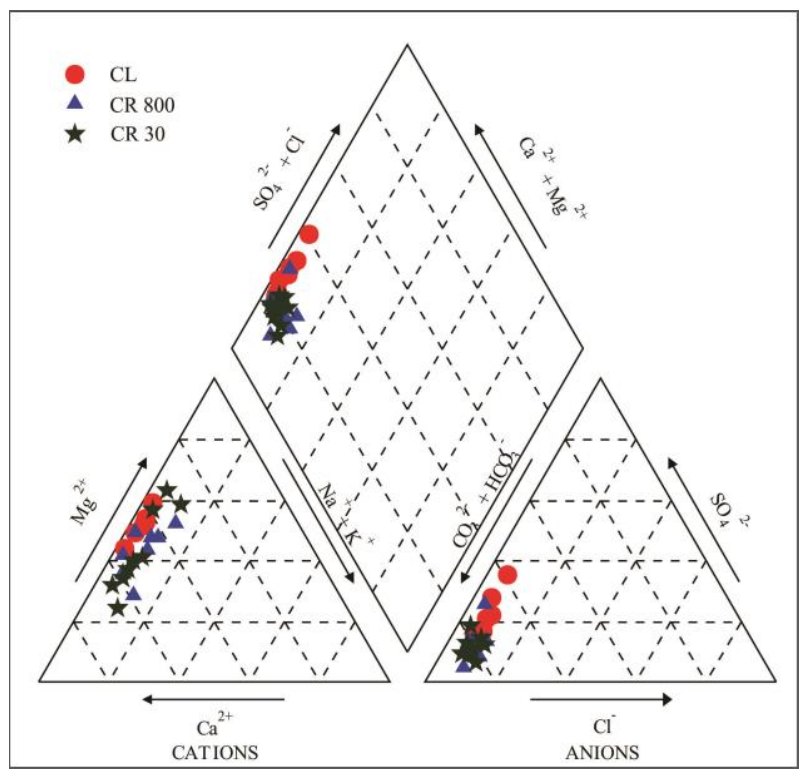

Figure 3. Piper diagram of the ground waters from the cave of Slatinski Izvor

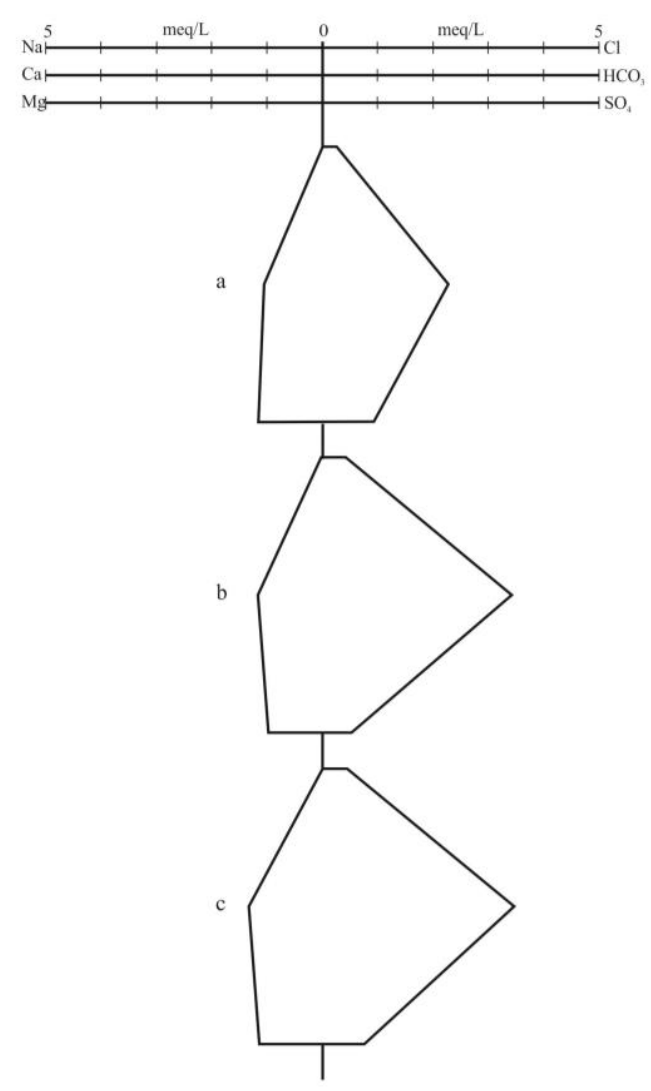

Figure 4. Stiff diagram of the cave Slatinski Izvor ( $\mathrm{a}-\mathrm{CL}, \mathrm{b}-\mathrm{CR} 800, \mathrm{c}-\mathrm{CR} 30)$

The water samples of the cave river and cave lake belong to D'Amore $\beta$ type which is represented by typical $\mathrm{CaHCO}_{3}$ type water. Almost identical shape can be seen for the samples CR800 and CR30 (Figure 6). 


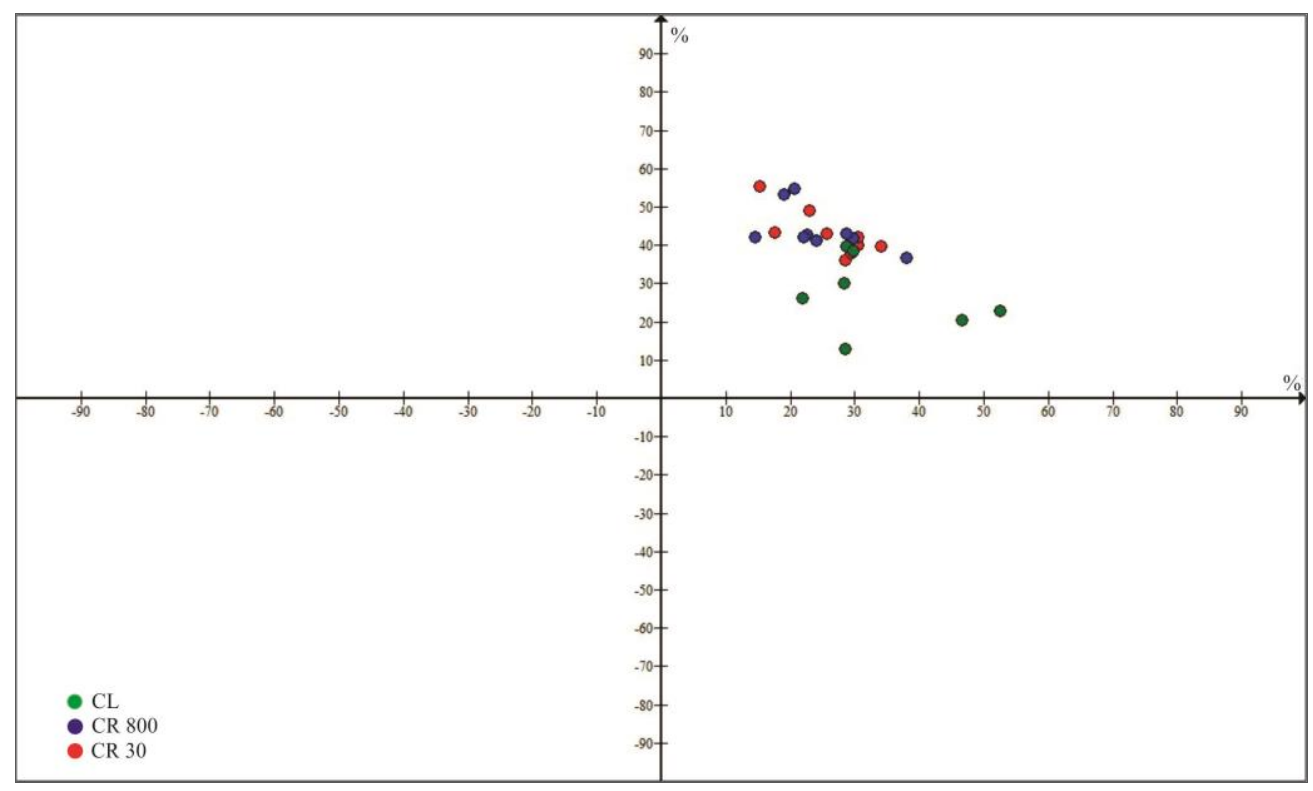

Figure 5. Chadha diagram of the ground waters from the cave of Slatinski Izvor

The high values of the A parameter and negative values of the $\mathrm{D}$ parameter point out to water circulation through carbonate rocks, and the influence of dolomite rocks is great. The low values of the $\mathrm{B}$ parameter and the negative values of the $C$ parameter point out that water is not in contact with clay sediments. The positive values of the $\mathrm{E}$ parameter point out to water circulation through sulphates rocks. The value of the $\mathrm{F}$ parameter emphasizes that $\mathrm{Ca}$ content is significantly higher in relation to $\mathrm{Na}$ and $\mathrm{K}$.

Very similar shape can be seen of the cave lake. The higher values of the $\mathrm{B}$ and the $\mathrm{E}$ parameters show that the concentration of sulphate is higher compared to the water samples of the cave river.

\section{Trace elements}

Eight trace elements $(\mathrm{Cu}, \mathrm{Cd}, \mathrm{Co}, \mathrm{Pb}, \mathrm{Mn}$, $\mathrm{Zn}, \mathrm{Fe}, \mathrm{P}$ ) were analyzed (Table 2). The concentrations of trace elements in water depend on aquifer mineralogy and on water-rock interaction. Their concentrations in the ground waters were low. The highest concentration had $\mathrm{Cu}$, and mutually with $\mathrm{Mn}$ and $\mathrm{Cd}$ originating from dissolution of carbonates and oxidation of sulphides [19].

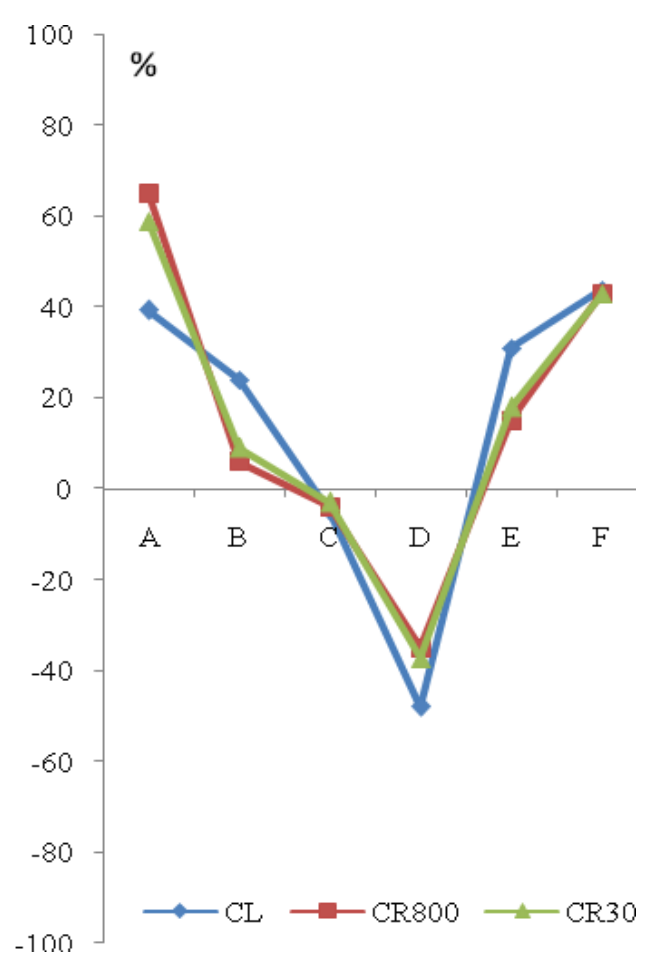

Figure 6. D'Amore rectangular diagram for water samples of the cave of Slatinski Izvor

Table 2. Trace elements in the water samples

\begin{tabular}{cccc|lccc}
\hline & \multicolumn{3}{c|}{ Concentration range $\left(\mu \mathrm{g} \cdot \mathrm{l}^{-1}\right)$} & \multicolumn{3}{c}{ Concentration range $\left(\mathrm{mg} \cdot \mathrm{l}^{-1}\right)$} \\
\cline { 2 - 8 } & $\mathrm{CL}$ & CR800 & CR30 & & CL & CR800 & CR30 \\
\hline $\mathrm{Cu}$ & $1.625-3.750$ & $1.429-3.500$ & $1.500-9.438$ & $\mathrm{Mn}$ & $0.002-0.006$ & $0.000-0.003$ & $0.000-0.033$ \\
$\mathrm{Cd}$ & nd-0.013 & nd-0.152 & $0.005-0.300$ & $\mathrm{Zn}$ & $0.003-0.007$ & $0.002-0.100$ & $0.003-0.015$ \\
$\mathrm{Co}$ & nd-0.044 & nd-0.023 & nd-0.776 & Fe & $0.048-0.304$ & $0.022-0.101$ & $0.018-0.094$ \\
$\mathrm{~Pb}$ & nd-0.005 & nd-0.078 & nd-0.005 & $\mathrm{P}$ & $0.002-0.020$ & $0.000-0.085$ & $0.000-0.073$ \\
\hline
\end{tabular}




\section{Saturation state}

Saturation indices of the water samples are presented in Table 3. All water samples of CL are undersaturated with respect to anhydrite, aragonite, calcite, dolomite, gypsum and halite minerals. Sampling point CR800 showed that water is under- saturated with respect to anhydrite, gypsum and halite, and undersaturated or slightly saturated with respect to aragonite, calcite and dolomite minerals. Water samples of CR30 are generally undersaturated or slightly saturated for aragonite, calcite and dolomite, and undresaturated for anhydrite, gypsum and halite.

Table 3. Saturation indices of the water samples

\begin{tabular}{|c|c|c|c|c|c|c|}
\hline $\begin{array}{c}\text { Date of } \\
\text { sampling }\end{array}$ & Anhydrite & Aragonite & Calcite & Dolomite & Gypsum & Halite \\
\hline \multicolumn{7}{|c|}{ Sampling point: CL } \\
\hline 08.2012 & -2.273 & -0.975 & -0.821 & -1.741 & -2.176 & -9.563 \\
\hline 10.2012 & -2.523 & -1.285 & -1.131 & -2.185 & -2.420 & -9.270 \\
\hline 11.2012 & -2.457 & -0.867 & -0.713 & -1.634 & -2.348 & -9.353 \\
\hline 07.2013 & -2.244 & -0.297 & -0.143 & -0.331 & -2.146 & -9.289 \\
\hline 08.2013 & -2.707 & -0.204 & -0.051 & -0.128 & -2.610 & -9.346 \\
\hline 09.2013 & -2.537 & -0.449 & -0.295 & -0.622 & -2.439 & -9.287 \\
\hline 10.2013 & -2.714 & -0.482 & -0.327 & -0.681 & -2.606 & -9.554 \\
\hline \multicolumn{7}{|c|}{ Sampling point: CR800 } \\
\hline 12.2011 & -2.572 & -0.352 & -0.196 & -0.753 & -2.452 & -8.721 \\
\hline 07.2012 & -2.552 & -0.227 & -0.072 & -0.239 & -2.427 & -8.681 \\
\hline 08.2012 & -2.590 & -0.190 & -0.035 & -0.315 & -2.482 & -9.439 \\
\hline 10.2012 & -2.450 & -0.847 & -0.692 & -1.518 & -2.331 & -9.213 \\
\hline 11.2012 & -2.643 & -0.969 & -0.814 & -2.089 & -2.523 & -8.413 \\
\hline 07.2013 & -2.497 & 0.014 & 0.168 & 0.003 & -2.389 & -8.743 \\
\hline 08.2013 & -2.659 & -0.291 & -0.137 & -0.363 & -2.550 & -8.759 \\
\hline 09.2013 & -2.836 & -0.532 & -0.378 & -0.709 & -2.727 & -8.633 \\
\hline 10.2013 & -3.032 & -0.205 & -0.049 & -0.276 & -2.912 & -8.709 \\
\hline \multicolumn{7}{|c|}{ Sampling point: CR30 } \\
\hline 12.2011 & -2.318 & -0.350 & -0.194 & -0.780 & -2.187 & -8.692 \\
\hline 07.2012 & -2.850 & -0.372 & -0.217 & -0.284 & -2.731 & -8.727 \\
\hline 08.2012 & -2.166 & 0.147 & 0.301 & 0.779 & -2.057 & -8.879 \\
\hline 10.2012 & -2.602 & -1.089 & -0.933 & -1.853 & -2.482 & -9.163 \\
\hline 11.2012 & -2.608 & -0.807 & -0.652 & -1.874 & -2.488 & -8.403 \\
\hline 07.2013 & -2.501 & -0.074 & 0.080 & -0.092 & -2.392 & -8.750 \\
\hline 08.2013 & -2.395 & 0.223 & 0.377 & 0.339 & -2.286 & -8.787 \\
\hline 09.2013 & -2.697 & -0.343 & -0.189 & -0.590 & -2.589 & -8.762 \\
\hline 10.2013 & -2.535 & 0.111 & 0.266 & 0.211 & -2.415 & -8.782 \\
\hline
\end{tabular}

\section{REFERENCES}

[1] D. Ford and P. Williams, Karst Hydrogeology and Geomorphology, John Willey \& Sons Ltd, England, 2007.

[2] D. Hunkeler, J. Mudry, Hydrochemical methods, pp. 93-121. In: N. Goldscheider, D. Drew, Methods in Karst Hydrogeology, Taylor \& Francis Group, London, 2007.

[3] M. Lopez-Chicano, M. Bouamama, A. Vallejos, A. Pulido-Bosch, Factors which determine the hydrogeochemical behavior of karstic springs. A case study from the Betic Cordilleras, Spain, App. Geochem., 16 (2001), pp.1179-1192.

[4] N. Dumurđanov, R. Stojanov, K. Petrovski, Explanatory note of the General Geological Map of
Kruševo 1:100000 map sheet. Federal Geological Survey of Yugoslavia, Belgrad, 1979.

[5] N. Dumurđanov, R. Stojanov, K. Petrovski, Geological Map of Kruševo 1:100000 map sheet (K34-91). Geološki zavod, Skopje, 1978.

[6] N. Dumurdzanov, T. Serafimovski, B. C. Burchfiel, Cenozoic tectonics of Macedonia and its relation to the South Balkan extensional regime, Geol. Soc. Am.: Geosphere, 1, no. 1 (2005), pp.1-22.

[7] B. Petreska, Slatina spring, Bull. of Phys. Geogr., 1 (2004), pp.87-95.

[8] N. A. Palmer, Origin and morphology of limestone caves, Geol. Soc. Am. Bull., 103 (1991), pp. 1-21.

[9] I. Dévai, K. Horváth and Gy. Dévai, Sulphate content determination of natural waters and description of a new photometric procedure, Acta Biol. Debrecina, 10-11 (1973), 129-142 (in Hungarian). 
[10] Škunca-Milovanović, S., R. Feliks, and B. Đurović (eds.), Voda za piće - Standardne metode za ispitivanje higijenske ispravnosti, Beograd: Savezni zavod za zdravstvenu zaštitu, 844 str., 1990.

[11] S. E. Allen (ed.), Chemical analysis of ecological materials, Blackwell scientific publication. Oxford-London-Edinburgh-Boston-Melbourne, pp. 46-61, 1989.

[12] C. H. Fiske and Y. Subbarow, The colorimetric determination of phosphorus, J. Bio. Chem., 66 (1925), 375-383.

[13] A. M. Piper, A graphical procedure in the geochemical interpretation of water analyses, $\mathrm{Am}$. $\mathrm{Ge}$ oph. Union Trans., 25 (1944), pp. 914-923.

[14] H. A. J. R. Stiff, The interpretation of chemical water analysis by means of patterns, J. Petrol. Technol., 3, no. 10 (1951), pp. 15-17.
[15] D. K. Chadha, A proposed new diagram for geochemical classification of natural waters and interpretation of chemical data, Hydrogeol. J., 7 (1999), pp. 431-439.

[16] F. D’Amore, G. Scandiffio, C. Panichi, Some observations on the chemical classification of ground waters, Geothermics, 12 (1983), pp. 141-148.

[17] L. N. Plummer, B. F. Jones, A. H. Truesdell, WATEQF - A Fortran IV version of WATEQ, A Computer program for calculating chemical equilibria of natural waters, U. S. Geological Survey, Water Resources Investigation Report 13 (1976), Reston.

[18] G. N. Sawyer, D. L. McCarthy, Chemistry of Sanitary Engineers ( $2^{\text {nd }}$ edn), McGraw Hill, New York, 1967.

[19] S. Kilchmann, H. N. Waber, A. Parriaux, M. Bensimon, Natural tracers in recent groundwaters from different Alpine aquifers. Hydrogeol. J., 12 (2004), pp. 643-661.

\title{
ХИДРОХЕМИСКИ КАРАКТЕРИСТИКИ НА ПЕШТЕРСКОТО ЕЗЕРО И ПОДЗЕМНИОТ РЕЧЕН ТЕК ВО ПЕШТЕРАТА СЛАТИНСКИ ИЗВОР
}

\author{
Билјана Гичевски ${ }^{1}$, Славчо Христовски² \\ ${ }^{1}$ Истражувачко друштво „Урсус спелеос“, Скопје \\ ${ }^{2}$ Институт за биологија, Природно-математички факултет, Универзитет „Св. Кирил и Методиј“, \\ Скопје, Република Македонија
}

Во периодот од декември 2011 до октомври 2013 година еднаш месечно, во сувиот период од годината, беа анализирани хидрохемиските карактеристики на подземните води во пештерата Слатински Извор (5 анјони и 11 катјони). Примероци вода беа земени од три точки: првата на $30 \mathrm{~m}$ од влезот во пештерата, втората на 800 m од влезот во пештерата и третата - пештерското езеро, на 1000 m од влезот во пештерата. За да се утврдат хидрохемиските карактеристики на водата, беа применети четири методи (дијаграм на Рірег, дијаграм на Stiff, дијаграм на Chadha и дијаграм на D’Amore) . Резултатите покажаа дека сите примероци вода имаат исто потекло, сите примероци му припаѓаат на типот $\mathrm{CaHCO}_{3}$, водата има привремена тврдост и изданот е изграден од доломит и варовник.

Клучни зборови: подземни води во пештерата Слатински Извор; дијаграм на Piper; дијаграм на Stiff; дијаграм на Chadha; дијаграм на D'Amore 